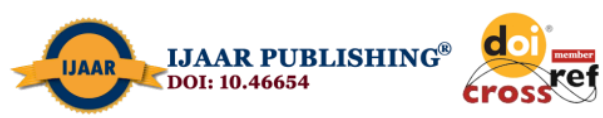

International Journal of Advanced Academic Research (Social and Management Sciences) | ISSN: 2488-9849

Vol. 6, Issue 6 (June, 2020) | www.ijaar.org

Journal DOI: 10.46654/ij.24889849

Article DOI: 10.46654/ij.24889849.s6616

\title{
EFFECT OF TREASURY SINGLE ACCOUNT (TSA) ON NIGERIAN BANKS PERFORMANCE
}

\author{
Echekoba, Felix Nwolisa \\ Department of Banking and Finance \\ Nnmadi Azikiwe University, Awka \\ E-mail: fn.echekoba@unizik.edu.ng \\ Obi-Nwosu, Vitoria Ogochukwu \\ Department of Banking and Finance \\ Nnmadi Azikiwe University, Awka \\ E-mail: vo.obi-nwosu@unizik.edu.ng \\ Ubesie, Cyril madubuko \\ Department of Accountancy \\ Enugu State University of Science and Technology, Enugu \\ E-mail: ubesiemadubuko@yahoo.com \\ Mbanefo, Patrick Amaechi \\ Department of Banking and Finance \\ Nnmadi Azikiwe University, Awka \\ E-mail: patmbanefo@yahoo.com
}

\begin{abstract}
This issue of TSA was as a result of leakages, embezzlement of funds and inadequate budgetary and financial planning. However the highest beneficiaries of this situation were the banks who relied on deposits from government agencies and lent back to the government at high interest rates. Some studies however, concludes that, proper implementation of TSA has helped tremendously in curbing mismanagement of public finances, corruption, block leakages and other financial irregularities in the country while others reported that in the public sector management and political economy of Nigeria, the impact of TSA has been a mixed bag of the good, the bad and the ugly Though there is mixed results about TSA, most of the studies based their reports on mere public opinion instead of raw data from government revenue via CBN Statistical Bulletin, this study ascertained whether Federal Government Deposit on credit to the private sector improved after the implementation of TSA in Nigeria. Ex post facto research design was adopted. Data was obtained from CBN Statistical Bulletin from 2011 to 2018. In testing the hypothesis, regression analysis was used with aid of E-view 9.0. The study concluded that the Federal Government Deposit has significantly improved on credit to the private sector after the implementation of TSA in Nigeria. On the bases of the finding, it was suggested that Central Bank should maintain a flexible monetary policy rate (MPR) at a minimum level in order to assist banks in taking alternative measures of meeting the emergency of cash withdrawal and lending demands of the customers.
\end{abstract}

Keywords: Treasury Single Account, Federal Government Deposit and Bank Performance. 


\section{INTRODUCTION}

Prior to the introduction to TSA, Nigeria had fragmented banking arrangement for revenue and payment transactions. These were more than 10,000 bank accounts in multiple banks which made it impossible to establish government consolidated cash position at any point in time. It led to pockets of idle cash balances held in MDA's account when government was out borrowing money (Obinna, 2015).

Treasury Single Account (TSA) is a financial policy used in several countries all over the world. It was introduced by the federal government of Nigeria in 2015 to consolidate all inflows from all agencies of government into a single account at the Central Bank of Nigeria (Ofurum, Oyibo \& Ahuche, 2018). Until the introduction of the Treasury Single Account (TSA) in Nigeria, Ministries, Departments and Agencies (MDAs) which generate revenue have had multiple accounts in commercial banks. The commercial banks used part of the amounts deposited with them to finance businesses and earn interest. As a result, agencies paid into government account what they deem fit as loopholes kept proliferating within the public sector (Oru \& Odumusor, 2019). The result of this situation included leakages of funds which are due the treasury, embezzlement of public funds, and inability of a government to know her account balances at a glimpse; budgets were prepared using unrealistic projections leading to poor implementation. However, the greatest beneficiaries of this situation were the banks that relied on the deposits from the MDAs and government borrowings from the banks with high-interest rates. Above all, banks no longer cared to mobilize deposits from other sectors of the economy as the balances of government accounts lay idle in the banks. All these stunted the growth of the economy.

This issue of TSA was as a result of leakages, embezzlement of funds and inadequate budgetary and financial planning. However the highest beneficiaries of this situation were the banks who relied on deposits from government agencies and lent back to the government at high interest rates. The banks however, operated "arm chair banking" as they no longer mobilized funds from other sectors of the economy. On this note, the federal government directed all MDAs to close their accounts with commercial banks and transfer the balances into the federation account with the Central Bank of Nigeria which was conveyed in a CBN circular titled "Commencement of Federal Government's Independent Revenue Collection Scheme under the Single Treasury Account (TSA) Initiative" on February 25, 2015 and addressed to all Deposit Money Banks (DMB). The TSA is a unified structure of government bank accounts enabling consolidation and optimal utilization of government cash resources. Through this bank account or set of linked bank accounts, the government transacts all its receipts and payments and gets a consolidated view of its cash position at any given time (Yusuf, 2016).

Pattanayak and Fainboim (2010) posit that government banking arrangement is an important factor for efficient management and control of government's cash resources. Many emerging market and low-income countries have fragmented systems for handling government receipts and payments. In these countries, the ministry of finance/treasury lacks a unified view and 
centralized control over government's cash resources (Pattanayak \& Fainboim, 2010). As a result, this cash lies idle for extended periods in numerous bank accounts held by spending agencies while the government continues to borrow to execute its budget.

Since the implementation of Treasury Single Account (TSA) in 2015 by the present administration in government with the intention to control financial mismanagement which will consequently improve government revenue and economic growth; stakeholders, researchers and the general public are interested to know the extent to which these objectives have been met. Meanwhile, Onuorah and Chigbu (2016) documented that Treasury Single Account deposit: federal government demand deposit, Federal government time deposit and Federal Government savings deposit have positive impact on the bank performance in Nigeria. Some studies conclude that, proper implementation of TSA has helped tremendously in curbing mismanagement of public finances, corruption, block leakages and other financial irregularities in the country while others reported that in the public sector management and political economy of Nigeria, the impact of TSA has been a mixed bag of the good, the bad and the ugly.

Though there is mixed results about TSA, most of the studies based their reports on mere public opinion instead of raw data from government revenue via CBN Statistical Bulletin, this study ascertained whether Federal Government Deposit on credit to the private sector improved after the implementation of TSA in Nigeria.

\section{REVIEW OF RELATED LITERATURE Conceptual Framework}

The background of Treasury Single Account (TSA) is in line with the presidential Order No. 55 (2011), which stipulated that the Bureau of Treasury (BTR) will institute a Treasury Single Account to receive and remit collections of internal revenue taxes/customs duties from Bureau of Internal Revenue/Bureau of Customs, authorized money depositing banks and also National Government Agencies from authorized government depository banks. The TSA will be maintained at the Central Bank of Nigeria (CBN) (Ofor, Omaliko \& Okoli, 2017).

The Central Bank of Nigeria therefore created an account called the 'Consolidated Account' to receive all government revenue and effect payments. This account is referred to as the Treasury Single Account. In 2012 the Nigerian government ran a pilot scheme for a single account using 217 ministries, departments and agencies as a test case. The pilot scheme saved Nigeria about N500 billion in frivolous spending. The success of the pilot scheme motivated the government to fully implement TSA, leading to the directives to banks to implement the technology platform that will help accommodate the TSA scheme. The recent directives by President Mohammed Buhari that all government revenues should be remitted to a Treasury Single Account is in consonance with this programme and in compliance with the provisions of the 1999 constitution (CBN, 2015). All Ministries, Departments and Agencies are expected to remit their revenue collections to this account through individual deposit money 
banks who act as collection agents. With this arrangement, the money deposit banks will continue to maintain revenue collection accounts for Ministries, Departments and Agencies but all monies collected by these banks will have to be remitted to the Consolidated Revenue Accounts with the $\mathrm{CBN}$ at the end of each banking day.

In practical terms, the accounts of Ministries, Departments and Agencies (MDAs) the deposit money banks must be zero-rated at the end of each banking day by a complete remittance to the Treasury Single Account of all monies collected (Ekubiat \& Ime, 2016). Different types of account are operated in a Treasury Single Account arrangement and these may include the TSA main account, subsidiary or subaccounts, transaction accounts and zero balance account. Other types of accounts that could operate include impress accounts, transit accounts and correspondence accounts. These accounts are maintained for transaction purposes for funds flowing in and out of the Treasury Single Account (Adeolu, 2015).

Treasury Single Account (TSA) is one of the financial policies implemented by the Federal Government of Nigeria to consolidate revenue from all ministries, departments and agencies (MDAs) in the country by way of deposits into commercial Banks traceable into a single account at the Central Bank of Nigeria. The policy was introduced to reduce the proliferation of bank accounts operated by MDAs and also to promote transparency and accountability among all organs of the government. Tayo (2015), said that TSA is "The Federal Government independent revenue e-collection initiative that will automate revenue collections of ministries, departments and agencies (MDAs) directly into the Federal Government consolidated revenue fund (CRF) account at the CBN through the Remitta e-collection and other electronic payment channels". Adeolu (2015) said the adoption of the TSA will involve retail banking which DMBs perform as deposits will yet be made to DMBs and can collect taxes/levies and make disbursements as well as payment of salaries to civil servants, but must operate a zero (0) balance account for all revenue receipt as monies are expected to be transferred electronically to the Consolidated Revenue Account (CRA) at the end of every banking day, hence leaving the banks with no public funds to ensure their operations at no cost of such capital. As a public accounting system, the primary aim of the TSA is to ensure accountability of government revenue, enhance transparency and avoid misapplication of public funds. The few exceptions to the TSA bother on the accounts operated by joint venture partners with government like oil, mining, leases (OMLS) in the oil and gas industry which are not paid to the Consolidated Revenue Funds (CBN, 2015).

Kanu (2016) views TSA as one of the financial policies implemented by the federal government of Nigeria to integrate all revenues and treasuries from all ministries, departments and agencies and extra ministerial departments in the country where all the collections are paid into money depositing banks trailed to a single account at the apex bank of the nation (CBN). Thus, the introduction of TSA was expected to reduce the multiplicity of bank accounts previously maintained by various MDAs, thus, ensuring transparency and accountability in all organs of the government. Tayo (2015) documented that by implementing the TSA, the Federal Government through its independent revenue e-collection 
initiative, hopes to automate direct revenue collection from the existing MDAs. All revenues collected would be paid directly into the Consolidated Revenue Fund (CRF) account at the CBN through a designed platform (Remita e-collection platform) and several other electronic payment platforms or channels that may be introduced by the government from time to time. Infact, TSA is seen as a structure that unifies government bank accounts that gives an amalgamated or integrated view of government's cash resources (Yusuf \& Chiejina, 2015).

\section{Treasury Single Account and Nigerian banks}

In Nigeria, banks have been the custodians of government funds (Kanu, 2016). Therefore, with the maintenance of a single account, banks will be deprived of the free flow of funds from ministries. Indeed, it is estimated that commercial banks hold about N2.2 trillion public sector funds at the beginning of the first quarter of 2015. When such amount of money leaves the system is obvious. When one considers the fact that each time the monthly federal allocation is released, the banking system is usually awash with liquidity, and as soon as this public sector fund dries up, the result is liquidity problem with an increase in interbank rates. The banks must be affected, when such high revenue generating parastatals like the NNPC moves out of commercial banks (Kanu, 2016). As a matter of fact, TSA generated much fear in the banking industry even before its implementation. The fear is that with the high Monetary Policy Rate at 13\%, Cash Reserve Ratio (CRR) at 20\% and $75 \%$ available for private and public sector deposits respectively, its implementation would not be favourable to banks. Irrespective of how tough this policy will be on banks, it will perhaps compel the banks to focus on the funds of the real sector of the economy, rather than spending much on Federal Government projects, Oil \& Gas Transactions, Forex dealings, etc. Any commercial bank that fails to operate based on the core banking functions for which they were licensed must definitely close shop. This will cause heavy downsizing of staff, thereby increasing the unemployment rate in the country. The Guardian of August 16, 2015 argued that "the full implementation of the TSA will certainly reduce the banks' net liquidity position and hence constrain their ability to create credits and this will invariably affect their profitability (Tari, Pwafeyeno, \& Minnessi, 2016).

However, Ocheni (2016) opines that the full implementation of the TSA will not be hurting banks. It will only hurt establishments that purport and pretend to be banks but have failed, refused and neglected to understand banking and do what bankers do elsewhere. It is an opportunity for banks to refocus on the original purposes for which they were set up to collect depositors' funds, keep them safe; engage in intermediation to create wealth and jobs for the economy and in the process earn profit for themselves.

\section{Review of Empirical Studies}

The Federal Government's directive to all revenue-generating agencies to close their accounts with commercial banks by February 28, 2015 and transfer same into a Consolidated Revenue Fund of the Federation and Treasury Single Account as a new electronic revenue collecting platform implemented recently by President Buhari has continued to generate 
debate across the country. Since then some studies have been carried out in this area. Oru and Odumusor (2019) assessed the effects of Treasury Single Account (TSA) on the Liquidity of Deposit Money Banks and effective control of government cash resources in Nigeria. A survey research design was employed in this study and data was obtained from primary source. Person's moment coefficient of correlation was used to test hypothesis and the study revealed that the policy implementation and its model has significant impact on the liquidity of Deposit Money Banks and the policy implementation has not afforded government effective control of its cash resources as accountability and transparency are not yet at their peak. Ofurum, Oyibo and Ahuche (2018) examined the extent to which TSA has improved Federally Collected Revenue (FCR) and Gross Domestic Product (GDP) of the economy. The data were divided into two periods: Pre TSA period (Q3-2013 to Q2-2015) and Post TSA period (Q3-2015 to Q2-2017). A pre post analysis (difference in means test) was carried out using SPSS version 20. Analysis shows that the implementation of TSA has a negative and significant effect on FCR. Saratu, Lenka, Levi and Titus (2017) ascertained the effect of implementation of Treasury Single Account (TSA) on the banking sector and the economy of Nigeria as a whole. The non-parametric chi square distribution was used to test the hypothesis developed. It was revealed from the analysis, that supervision exercised on MDAs' revenue generation and collection is not good enough. Ndubuaku, Ohaegbu and Nina (2017) determined the impact of TSA on the performance of the banking system in Nigeria. This research study sought to determine the impact of TSA on Credit to the Private Sector, Deposit Mobilization and Loans and Advances respectively. Secondary and time series data were obtained from the CBN statistical bulletin 2015. The data were analysed using regression and correlation analysis. The results from the research analysis confirmed that the TSA had a significant impact on Credit to the Private Sector, Deposit Mobilization and Loans and Advances. Akujuru and Enyioko (2017) examined the effects of Treasury Single Account policy on corruption in Nigeria: analysis from 2011 to 2017. The study adopted a cross sectional survey design and used questionnaire to generate its data. The data were analyzed through the use of descriptive statistics. The study found that the treasury single account (TSA) policy was introduced to block financial leakages, reduce corruption, promote transparency and prevent mismanagement of government's revenue in public sector organizations. The study revealed that the major challenges hampering the effective and efficient implementation of the Treasury Single Account (TSA) policy include: Inability of federal government to remit appropriately to the various MDAs, uncertainties underlying federal government inactions. Udo and Esara (2016) evaluated the benefit of the adoption and full implementation of TSA by the state governments of Nigeria. Descriptive cross- sectional survey design was adopted for the study. The population for the study consisted of 200 Professional Accountants in Akwa-Ibom State. The data obtained from questionnaire administration were analysed using descriptive statistics and t-test statistics. The finding reveals that, TSA adoption and full implementation by the state governments will be of greatest benefit. 
The study carried out by Ekubiat and Ime (2016) on the benefits, challenges and prospects of Treasury Single Account (TSA) adoption by State Governments of Nigeria on a sample of professional Accountants in Akwa Ibom State identified and ranked the statement that the adoption of TSA "enable government to know how much is accruing to it on a daily basis, thus, reduces corruption". Kanu (2016) assesses the positive effect of implementation of TSA on the economy, the public accounting system and the undesired consequences on the liquidity base and performance of banking sector in Nigeria. The study employed Chi-square as a statistical tool for analysis of the data. The results obtained confirmed that the implementation of Treasury Single Account in the public accounting system impacted negatively on the liquidity base and the performance of banking sector in Nigeria. Onuorah and Chigbu (2016) assessed the effect of implementation of Federal Government Treasury Single Account (TSA) Deposits and commercial banks performance in Nigeria. Time series data were collected from Central Bank of Nigeria (CBN) Statistical Bulletin (2015) for the period 2012 to 2016. The study employed trend analysis (bar charts) and SPSS 7.0 software, descriptive statistics and least square test. The results obtained revealed that the implementation of Treasury Single Account deposit; federal government demand deposit (LnFGDD), Federal government time deposit (LnFGTD), and Federal Government savings deposit (LnFGSD) have positive impact on the bank performance in Nigeria. LnFGSD impacted negatively on LnCBP in Nigeria. The study shows that the overall variables are not statistically significant as p-value f- stat $(0.88>0.05)$ significant level. Onuorah and Appah (2012) examined the management of public funds in terms of how public office holders give accountability report of their stewardship. Data on total federal government revenue and expenditure, state governments' revenue and expenditure were collected from Statistical Bulletin from the Central Bank of Nigeria from 1961-2008. The results were analyzed using relevant statistical tools. The findings reveal that the level of accountability is very poor in Nigeria because the attributes of accessibility, comprehensiveness, relevance, quality, reliability and timely disclosure of economic, social and political information about government activities are completely non available or partially available for the citizens to assess the performance of public officers mostly the political office holders.

Though the prior results are uncertain about TSA in Nigeria, most of the studies based their reports on mere public opinion instead of raw data from government revenue via CBN Statistical Bulletin.

\section{METHODOLOGY}

Ex-post fact research design and time series data which is the aspect of statistic that involves the various techniques of describing data collections have been adopted for the purpose of this research. This design will also enable the researcher describe and summarize the data collected for the purpose of this study and enable an in-depth knowledge about the objectives and the variables of the study. 


\section{Population of the Study}

The population of this study consists of the 16 deposit money banks quoted on the Nigerian Stock Exchange. The study covered eight years annual reports and accounts of Central Bank of Nigerian Statistical Bulletin from 2011 to 2018.

\section{Sources of Data Collection}

The data was sourced from publications of CBN Statistical Bulletin. The data extracted include; Federal government deposits and credit to private sector.

\section{Model Specification}

This study adopted Mayandy (2012) model of the Wagner's Law in Sri Lanka. The model can be represented in the following form:

$\mathrm{Y}=\beta_{\mathrm{o}}+\beta_{1} \mathrm{X}_{1}+\mu$

Where:

$\mathrm{Y}=$ performance (dependent variable)

$\mathrm{X}=$ Treasury Single Account of Federal Government (independent Variable)

$\beta_{0}=$ constant term (intercept)

$\beta_{1}-\beta_{3}=$ Coefficients of Federal Government Deposit

$\mu=$ Error term (stochastic term)

Explicitly, the equation can be defined as:

Performance $=f($ Federal Government deposit $)+\mu$

Representing the equations with the variables of the construct, hence the equations below are formulated:

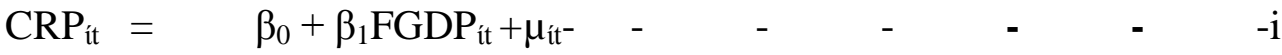

Where:

$\beta_{0}=$ Constant term (intercept)

$\beta_{\mathrm{it}}=$ Coefficients to be estimated for $\mathrm{i}$ in period $\mathrm{t}$

$\mu_{\mathrm{it}}=$ Error term/Stochastic term for $\mathrm{i}$ in period $\mathrm{t}$

FGDP $_{i t}=\quad$ Federal Government Deposit $i ́$ in period $t$ (independent variable)

$\mathrm{CRP}_{\text {it }}=\quad$ Credit to private sector $\mathrm{i}$ in period $\mathrm{t}$ (dependent variable)

\section{Method of Data Analysis}

Ordinary Least Square was used to test the relationship between the independent variable and the dependent variables. This was done with aid of the E-view version 9.0 at five degree of freedom (df).

\section{Decision Rule}

The decision for the hypothesis is to accept the alternative hypothesis if the p-value of the test statistic is less or equal than the alpha and to reject the alternative hypothesis if the p-value of the test statistic is greater than alpha at 5\% significance level. 
Journal DOI: 10.46654/ij.24889849

Article DOI: 10.46654/ij.24889849.s6616

\section{DATA PRESENTATION AND ANALYSIS}

\subsection{Data Analysis}

\section{Hypothesis One}

$\mathrm{Ho}_{1}$ : The Federal Government Deposit has not significantly improved on credit to the private sector after the implementation of TSA in Nigeria.

Dependent Variable: FGDP

Method: Least Squares

Date: 01/25/20 Time: 23:11

Sample: 20112014 (Before TSA)

Included observations: 4

\begin{tabular}{lrlrr}
\hline \hline \multicolumn{1}{c}{ Variable } & Coefficient & \multicolumn{1}{c}{ Std. Error } & t-Statistic & Prob. \\
\hline \multicolumn{1}{c}{ CRP } & -2235.679 & 1327.824 & -1.683716 & 0.1908 \\
\multicolumn{1}{c}{ CRP } & 0.284584 & 0.107475 & 2.647915 & 0.0771 \\
\hline \hline R-squared & 0.700343 & Mean dependent var & 1200.140 \\
Adjusted R-squared & 0.600458 & S.D. dependent var & 997.2136 \\
S.E. of regression & 630.3324 & Akaike info criterion & 16.01955 \\
Sum squared resid & 1191957. & Schwarz criterion & 15.86332 \\
Log likelihood & -38.04886 & Hannan-Quinn criter. & 15.60025 \\
F-statistic & 7.011454 & Durbin-Watson stat & 2.388910 \\
Prob(F-statistic) & 0.077131 & & \\
\hline \hline
\end{tabular}

Source: E-View 9.0

Dependent Variable: FGDP

Method: Least Squares

Date: 01/25/20 Time: 23:17

Sample: 20152018 (After TSA)

Included observations: 4

\begin{tabular}{lrlrr}
\hline \hline \multicolumn{1}{c}{ Variable } & Coefficient & \multicolumn{1}{c}{ Std. Error } & t-Statistic & Prob. \\
\hline \multicolumn{1}{c}{ C } & 1412.384 & 435.8561 & 3.240483 & 0.0478 \\
\multicolumn{1}{c}{ CRP } & 0.099703 & 0.018463 & 5.400152 & 0.0124 \\
\hline \hline R-squared & 0.906721 & Mean dependent var & 3713.480 \\
Adjusted R-squared & 0.875628 & S.D. dependent var & 580.9440 \\
S.E. of regression & 204.8779 & Akaike info criterion & 13.77188 \\
Sum squared resid & 125924.9 & Schwarz criterion & 13.61565 \\
Log likelihood & -32.42970 & Hannan-Quinn criter. & 13.35259 \\
F-statistic & 29.16165 & Durbin-Watson stat & 2.399445 \\
Prob(F-statistic) & 0.012447 & & \\
\hline \hline
\end{tabular}

Source: E-View 9.0

The table above shows the Panel Least Square regression result for hypothesis one. The model showed an $\mathrm{R}$ squared value of .700(.906) $\left(\mathrm{R}^{2}\right.$ measures the proportion of the variance in the dependent variable that is explained by the independent variables); thus, the model explains approximately $70 \%$ (91\%) variation in the dependent variable. The F-statistic (ratio of the mean regression sum of squares divided by the mean error sum of squares) which is 
used to check the statistical significance of the model showed a value of 7.011454 (29.16165); $\mathrm{p}$ value $<0.05$, therefore, the hypothesis that all the regression coefficients are zero is rejected.

The results illustrated that Federal Government Deposit has effect on credit to the private sector measured with a beta coefficient $\left(\beta_{1}\right)$ and t-value of $0.284584 ; 2.647915$ respectively and p-value of 0.077 , and this effect is not statistically significant before the implementation of TSA as its p-value is greater than 0.05 values. After the implementation of Treasury Single Account (TSA), the results illustrated that Federal Government Deposit has a positive and significant effect on credit to the private sector measured with a beta coefficient $\left(\beta_{1}\right)$ and tvalue of $0.099703 ; 5.400152$ respectively and $p$-value of 0.012 , was found to have a positive effect on our sampled variable and this effect is equally statistically significant as its p-value is less than 0.05 values. This result, therefore suggests that we should accept our alternative hypothesis one which states that the Federal Government Deposit has significantly improved on credit to the private sector after the implementation of TSA in Nigeria.

\section{CONCLUSION AND RECOMMENDATION}

From the result above, it can be seen that the implementation of Treasury Single Account has improved credit facilities in Nigeria. The analysis disclosed that Federal Government Deposit significantly increased during the period of its implementation. Based on the findings of the study, the study concludes that the Federal Government Deposit has significantly improved on credit to the private sector after the implementation of TSA in Nigeria.

On the bases of the finding, it was suggested that Central Bank should maintain a flexible monetary policy rate (MPR) at a minimum level in order to assist banks in taking alternative measures of meeting the emergency of cash withdrawal and lending demands of the customers. 


\section{REFERENCES}

Adeolu, I. A. (2015). Understanding The Treasury Single Account (TSA) system - things you should know. Business \& Economy, Market Development.

Akujuru, C. B. \& Enyioko, N. C. (2017). Effects of treasury single account policy on corruption in Nigeria. SSRN Electronic Journal .

Central Bank of Nigeria, [CBN] (2015). Revised guidelines for compliance with treasury single account by banks in Nigeria.

Chartered Institute of Public Finance and Accountancy [CIPFA], (2010). Public financial management: a whole system approach, Volume 1, 2010, page 5.

Ekubiat, J.U., \& Ime, E.E. (2016). Adoption of treasury single account (tsa) by state governments of Nigeria: benefits, challenges and prospects. Journal of Finance and Accounting, 4(3), 126-130. doi: 10.11648/j.jfa.20160403.14.

Kanu, C. (2016). Impact of treasury single account on the liquidity. ABC Journal of Advanced Research, 5(1).

Ndubuaku, V. C., Ohaegbu, O.K., \& Nina N. M. (2017). Impact of treasury single account on the performance of the banking sector in Nigeria. IOSR Journal of Economics and Finance (IOSR-JEF) 8(4) e-ISSN: 2321-5933, p-ISSN: 2321-5925.

Oru, A. O. \& Odumusor, C. J. (2019). Effect of treasury single account (tsa) on liquidity of deposit money banks and effective control of governments cash resources in Nigeria. IOSR Journal of Economics and Finance (IOSR-JEF) 10(1). e-ISSN: 2321-5933, pISSN: 2321-5925.

Ofurum, C. N., Oyibo, P. C., \& Ahuche, Q. E. (2018). Impact of treasury single account on government revenue and economic growth in Nigeria: A Pre - Post Design. International Journal Of Academic Research In Business And Social Sciences, 8(5), 283-292.

Obinna, C. (2015). Banks face liquidity strain as FG fully enforces Treasury Single Account. p. 52.

Ofor, N. T., Omaliko, L. E., \& Okoli, F. C. (2017). Effect of treasury single accounts (TSA) on the performance of ministries, departments and agencies (mda) in Nigeria. Trendy Ekonomiky A Management Trends Economics and Management ISSN 1802-8527 (Print) / ISSN 2336-6508 (Online)

Ocheni, S. (2016). Treasury single account: a catalyst for public financial management in Nigeria. The Nation. 
Onuorah, A. C. \& Chigbu, E. E. ,(2016). Federal government treasury single account (tsa) deposits and commercial banks performance. Journal of Social And Management Sciences . 11(3).

Onuorah, A. C. \& Appah, E. (2012). Accountability and public sector financial management in Nigeria. Arabian Journal of Business and Management Review, 1(6), 1-17.

Pattanayak, S., \& Fainboim, I. (2010). Treasury single account: concept, design and implementation issues. IMF Working Paper, No. WP/10/143.

Saratu L. J. S., Lenka, N. M. Levi J. Y. \& Titus, Ya. J.(2017). Assess the effect of treasury single account (TSA) on the Nigerian economy. IJMSR 2(1).

Tari, V. A., Pwafeyeno, M., \& Minnessi, G. (2016). Treasury single account (TSA) policy in Nigeria: reviving Jonathan's 'Dead' Policy Directives. Online Journal of Social Sciences Research, 5, 6-12.

Tayo, M. (2015). Recent innovations in treasury cash management. Current Issues in Economics and Finance, 10(12), pp.46-62.

Udo, J.E \& Esera, I.E.(2016). Adoption of treasury single account (TSA) by state governments of Nigeria. Benefits, challenges and prospects. Journal of finance and accounting volume 4(3) page 126-130.

Yusuf, I., \& Chiejina, N. (2015). Anti-Graft war: one economy, one account. Sunday nation, pp. 9-10,71.

Yusuf, M. (2016). Effects of treasury single account on public finance. Research Journal of Finance and Accounting, 7(6). 